
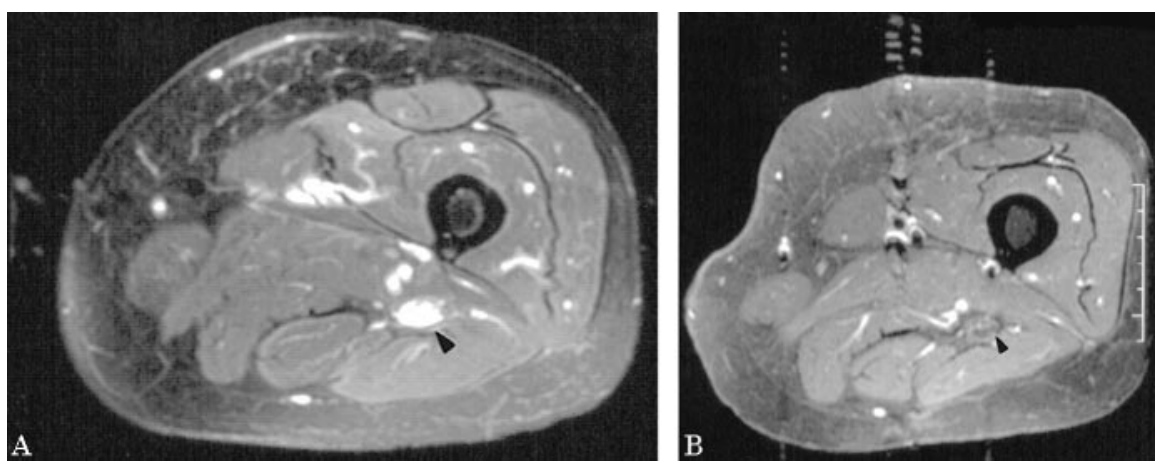

Neuro/mages

\section{Sciatic neurolymphomatosis}

Elias Dakwar, BA; Sandeep Teja, MD; and Cargill H. Alleyne, Jr., MD, Rochester, NY, and Augusta, GA

Mononeuropathy from neurolymphomatosis (NL) occurs in $15 \%$ of cases of NL. ${ }^{1}$ A 70 -year-old woman presented with left sciatica 22 years after diagnosis of marginal zone B-cell lymphoma. A gallium scan several weeks after symptom onset re-

Address correspondence and reprint requests to Dr. Cargill H. Alleyne, Jr., Department of Neurosurgery, Medical College of Georgia, 1120 15th St., BI 3088, Augusta, GA 30912; e-mail: calleyne@mail.mcg.edu vealed increased uptake in the left thigh, lacrimal glands, and maxillary sinus. MRI revealed a fusiform 5-cm lesion of the sciatic nerve above the knee (figure, A). An outside lumbar MRI scan was reported as negative, but was not available to us for review.

On exploration, the nerve was fleshy and soft. Biopsy revealed hypercellular CD20-positive cells with small round nuclei consistent with marginal zone B-cell lymphoma. After postoperative radiation therapy, an MRI at 1 year revealed a decrease in size and enhancement (see figure, B).

1. Baehring JM, Damek D, Martin EC, Betensky RA, Hochberg FH. Neurolymphomatosis. Neuro-oncol 2003;5:104-115. 


\section{Neurology}

Sciatic neurolymphomatosis

Elias Dakwar, Sandeep Teja and Cargill H. Alleyne, Jr.

Neurology 2004;63;1751

DOI 10.1212/01.WNL.0000138501.06028.68

This information is current as of November 8, 2004

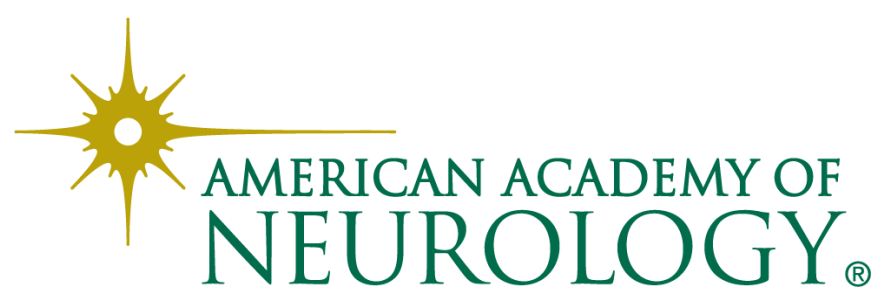




\section{Updated Information \& Services}

References

Citations

Subspecialty Collections

Permissions \& Licensing

Reprints including high resolution figures, can be found at: http://n.neurology.org/content/63/9/1751.full

This article cites 1 articles, 0 of which you can access for free at: http://n.neurology.org/content/63/9/1751.full\#ref-list-1

This article has been cited by 1 HighWire-hosted articles: http://n.neurology.org/content/63/9/1751.full\#\#otherarticles

This article, along with others on similar topics, appears in the following collection(s):

All Imaging

http://n.neurology.org/cgi/collection/all_imaging All Oncology

http://n.neurology.org/cgi/collection/all_oncology

Amyotrophic lateral sclerosis

http://n.neurology.org/cgi/collection/amyotrophic_lateral_sclerosis_ Hematologic

http://n.neurology.org/cgi/collection/hematologic

MRI

http://n.neurology.org/cgi/collection/mri

Nerve tumor

http://n.neurology.org/cgi/collection/nerve_tumor

Radiation therapy-tumor

http://n.neurology.org/cgi/collection/radiation_therapytumor

Information about reproducing this article in parts (figures,tables) or in its entirety can be found online at:

http://www.neurology.org/about/about_the_journal\#permissions

Information about ordering reprints can be found online:

http://n.neurology.org/subscribers/advertise

Neurology ${ }^{\circledR}$ is the official journal of the American Academy of Neurology. Published continuously since 1951, it is now a weekly with 48 issues per year. Copyright . All rights reserved. Print ISSN: 0028-3878. Online ISSN: 1526-632X.

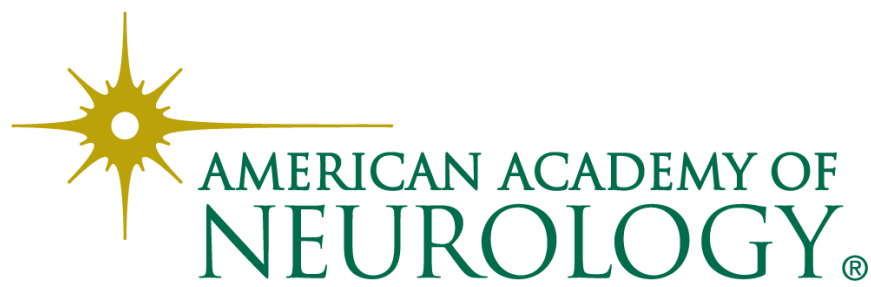

